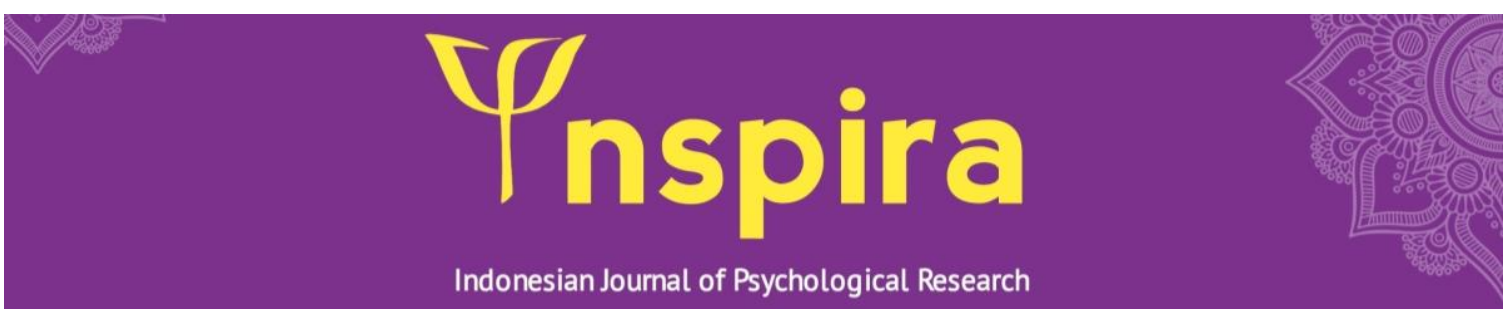

\title{
Healthy lifestyle module for improving the quality of life of chronic kidney disease patients
}

\author{
Idar Sri Afriyanti Zebua ${ }^{1 凶}$, Abdul Munir ${ }^{2}$, Irna Minauli ${ }^{3}$
}

${ }^{1,3}$ Department of Psychology, Universitas Medan Area, North Sumatera, Indonesia;

${ }^{2}$ Department Guidance and Counseling, Universitas Negeri Medan, North Sumatera, Indonesia;

\section{${ }^{凶}$ Corresponding author:}

Idar Sri Afriyanti Zebua (email: idar1975@gmail.com)

\begin{abstract}
Changing lifestyle or habits means changing one's perspective and changing their paradigm. The arrangement of good behavior through the provision of healthy lifestyle modules to patients undergoing hemodialysis therapy should be supported with high motivation. The study aims to find out the effect of providing healthy lifestyle modules and motivation to improve the quality of life of patients. This study is an experimental quasi-research with a $2 \times 2$ factorial design involving a sample of 30 chronic kidney disease patients undergoing hemodialysis therapy at Rumah Sakit Khusus Ginjal Rasyida Medan, North Sumatra, Indonesia. Through the analysis of multiple linear regression analysis, the results showed a significant influence between the provision of healthy lifestyle modules on improving quality of life. Other findings suggest differences in quality of life between patients with high motivation levels and low-motivated patients. This study proposes further studies to examine the effectiveness of modules and improve quality of life against different patient cultural backgrounds.
\end{abstract}

Article History:

Received: May 18, 2021

Revised: May 30, 2021

Accepted: June 29, 2021

Published: June 30, 2021

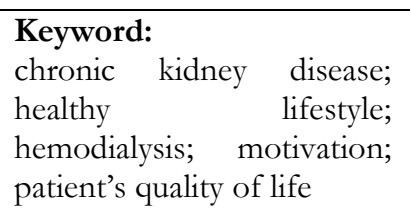

\section{How to cite (APA $7^{\text {th }}$ Edition)}

Zebua, I. S. A, Munir, A., \& Minauli, I. (2021). Healthy lifestyle module for improving the quality of life of chronic kidney disease patients. INSPIRA: Indonesian Journal of Psychological Research, 2(1), $22-33$. https://doi.org/10.32505/inspira.v1i1.3076

This is an open-access article distributed under the Creative Commons Attribution License, which permits unrestricted use, distribution, and reproduction in any medium provided the original work is properly cited. This is enabled under the terms of attribution and noncommercial usage of the material (C2021 by Idar Sri Afriyanti Zebua1, Abdul Munir, \&Irna Minauli 


\section{INTRODUCTION}

Lifestyle is one of the important internal factors that can affect health. Lifestyle refers to how a person behaves in their life, including the choice of residence and the pattern of behavior of the individual himself, and sociocultural factors and individual characteristics strongly influence this condition. Negative lifestyles such as smoking, alcohol consumption, inadequate activity, and rest will trigger the onset of various modern chronic diseases, and one of them is chronic kidney disease (Ratnawati, 2014).

Many evidence suggests that changing an individual's lifestyle towards a healthy lifestyle, both on a small scale and in society more broadly, can drastically reduce the incidence rate of modern chronic diseases and vice versa. Changing one's lifestyle or habits means having to change one's perspective and change one's paradigm.

The worldwide incidence of kidney disease globally is more than 500 million people and who have to live a life dependent on hemodialysis is 1.5 million people. In the United States, the incidence and prevalence of kidney disease increased by 50\% in 2014. Data shows that 200,000 Americans undergo hemodialysis due to chronic kidney disorders every year, meaning 1,140 in one million Americans are dialysis patients (Widyastuti, Butar-Butar, \& Bebasari, 2014).

According to Yayasan Peduli Ginjal, in 2014, there are currently 40,000 patients with chronic kidney disease in Indonesia. Of these, only about 3,000 patients can enjoy hemodialysis services, and the rest can only give up their lives due to various factors and, most importantly, economic factors. In undergoing hemodialysis therapy, the patient desires to improve his quality of life to take the patient's self-motivation because motivation is the key to success in undergoing treatment.

A common complication in hemodialysis patients is weight gain between two hemodialysis times (Interdialysis Weight Gain or IDWG) caused by the inability to function renal excretion. According to Hwang, Wang, \& Chien (2007), weight gain between two dialysis times is also influenced by several factors, namely: environment, nutrition, behavior, physiological and psychological.

Weight gain of zero milligrams is not possible. Kimmel et al. (2000) explained that the ideal weight gain between two hemodialysis times is $1.5 \mathrm{~kg}$. The addition of IDWG values that are too high will be able to cause negative effects on the patient's condition, including hypotension, muscle cramps, hypertension, shortness of breath, nausea, and vomiting, and others (Brunner \& Suddarth, 2005).

Kalantar-Zadeh \& Aronoff (2009) found that $86 \%$ of patients undergoing hemodialysis had an interdialytic weight of more than $1.5 \mathrm{~kg}$. In addition, data obtained that patients who have an interdialytic weight between 1.5-2.0 kg have a potential $25 \%$ the increased risk of death, and patients who have an interdialytic weight of more than $4.0 \mathrm{~kg}$ potentially $28 \%$ increase to the risk of death. At the same time, patients who have an interdialytic weight below $1.5 \mathrm{~kg}$ have a potential 26\%-33\% reduced risk of death. The onset of negative effects of weight gain between dialysis times will affect the quality of life of chronic renal failure patients until the onset of death, as revealed by the researchers above.

Quality of life is often interpreted as a component of happiness and satisfaction in life. However, understanding the quality of life often means different in each person because it has 
many factors that affect finance, safety, or health. Therefore, health-related quality of life term is used in health (Fayers \& Machin, 2013).

Disease prevention activities, quality of life is used as an aspect to describe health conditions. Quality of life is a level that describes the superiority of an individual that can be judged from their life. The individual's quality of life can usually be assessed from physical, psychological, social, and environmental relationships (Larasati, 2012).

Aspects of quality of life can be seen from the structure of the four domains of the World Health Organization Quality of Life Questionnaire-Short Version (WHOQOL-BREF, 1996), namely: (1) Physical health, which is good condition, means free from pain in the whole body and other parts. These aspects include daily activities, dependence on restorative materials and medical aids, energy and fatigue, mobility, pain and discomfort, sleep and rest, and work capacity; (2) Psychologically, it is related to the individual's mental state. The psychological aspect is also related to the physical aspect, where the individual can perform an activity well when the individual is mentally healthy. These aspects include body image and appearance, negative feelings, positive feelings, self-esteem, individual confidence, thinking, learning, memory, and concentration; (3) A social relationship, i.e., a relationship between two or more individuals in which the individual's behavior will influence, change or improve the behavior of another individual. These aspects include personal relationships, social support, and sexual activity; and (4) Environment, which is the residence of individuals, including the circumstances, the availability of a place to live to do all life activities, facilities, and infrastructure that can support life. These aspects include financial resources, freedom of physical safety and security, health and social: accessibility and quality of the home environment, opportunities to acquire new information and skills, participation and opportunities for recreational activities, physical environment, and transportation.

Anees, Hameed, Mumtaz, Ibrahim, \& Saeed Khan (2011) revealed that the quality of life of 89 kidney disease patients undergoing hemodialysis is at a low level for the domain of physical health, the psychological domain, while for the domain of social and environmental relations is at a moderate level.

The change in the quality of life and the improvement of IDWG are inseparable from the lifestyle lived by hemodialysis patients themselves. Low awareness in implementing a healthy lifestyle among patients undergoing hemodialysis therapy is also a trigger for the above factors.

An increase in IDWG exceeding the tolerance limit will impact various forms of complications and ultimately affect the quality of life of each patient undergoing dialysis therapy; medical officers and paramedics have anticipated this in the unit by educating in every shift of hemodialysis services.

However, the reality is that the improvement in the patient's quality of life has not met the real expectations. From the interviews we conducted on these patients, there was a low motivation and awareness to implement a healthy lifestyle in their lives, among others: uncontrolled eating habits, improper fluid restriction patterns, insufficient sleep and rest patterns, lack of physical activity, improper coping ability, family support, social and environmental relationships.

Studies focusing on the quality of life of chronic renal failure patients have been conducted several times. The study tried to review the picture of the quality of life (Nurmanita, Rosita, 
Nurjayanti, 2020; Supriyadi, Wagiyo, \& Widowati, 2011), level of knowledge (Sari, 2018; Aminah, 2012), and lifestyle history (Prakosa, 2011, Diyono \& Indriati, 2017). Some of them try to see the effects of gender (Ipo, Aryani, \& Suri, 2016), partner support (Zurmel, Bayhakki, \& Utami, 2015), family support (Maulida, Fadilah, \& Yulianto, 2019) as well as self-efficacy (Wakhid, Linda Wijayanti, \& Liyanovitasari, 2018) on the quality of life of patients. Some of them also offer interventions such as kidney diet therapy (Kurniawati \& Asikin, 2018), psychological intervention (Widayati \& Lestari, 2015), as well as efficacy training from (Sulistyaningsih, 2012).

However, studies to improve healthy lifestyles in chronic renal failure patients by administering healthy lifestyle modules have never been conducted. In fact, through the provision of the module, a patient can train himself independently to improve his quality of life. This study aims to identify the effect of healthy lifestyle modules to improve patients' quality of life with chronic renal failure.

\section{RESEARCH METHOD}

This study uses a quantitative approach with a quasi-experimental research type with a $2 \times 2$ factorial design. This design will be compared to the improved quality of life of the patients who undergo hemodialysis therapy to provide a healthy lifestyle module reviewed from the patient's motivation. The patient's motivation is distinguished by high motivation and low motivation. Provision of healthy lifestyle module as a free variable, during High motivation and low motivation as moderator variable and improvement of patient quality of life as a bound variable. The research design can be seen in Table 1 as follows:

Table 1 The 2x2 Experimental Factorial Design

\begin{tabular}{|l|l|l|}
\hline Motivation (M) & Experimental Group (EG) & Control Group (CG) \\
\hline High (M1) & QL1.M1 & QL2.M1 \\
\hline Low (M2) & QL1.M2 & QL2.M2 \\
\hline
\end{tabular}

Description:

The scheme of research design is as follows:

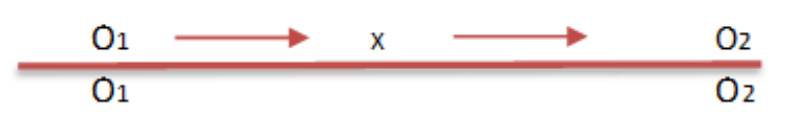

The subjects in this study were 30 chronic renal failure patients who underwent hemodialysis therapy at Rumah Sakit Khusus Ginjal Rasyida Medan, North Sumatra, Indonesia selected through purposive sampling techniques with the following criteria:
a. Subject age $20-55$ years.
b. The subject has undergone hemodialysis therapy for more than one year.
c. Conscious and able to communicate well.
d. Able to read well
e. Willing to be the subject of research by filling out informed consent 
The subjects of this study were divided into two groups, namely the treatment group or experimental group of 15 people and the control group of 15 people. The researchers conducted a pretest test on the subject with the help of the executive staff in the hemodialysis unit of Rumah Sakit Khusus Ginjal Rasyida Medan, North Sumatera, Indonesia which had previously been explained the procedure of implementation of the pretest. Pretest data from each subject are recorded in the data table.

This study was conducted following the schedule determined by sharing a motivational questionnaire as many as 15 statements that the study subjects must answer. The results of the motivation test are divided into two high and low categories when the score is 15-44 classified in the low category, and the score is 45-60 with the high category.

After the group's division was determined, all subjects of the experimental group were given the provision of healthy lifestyle modules to the research subjects of the experimental group with the evaluation of eight meetings. Nevertheless, before the module is given, the researcher gives information about using the module, and the researcher emphasizes that the honesty of the subject in checklist each item in the module should be by the activities that the subject does in behaving a healthy lifestyle while at home. In addition, researchers also gave examples (role play) to the subject on using models or selecting each item that corresponds to what is done in a healthy lifestyle. After eight meetings after the subject underwent 4 dialysis cycles (1 month after the intervention), post-test data retrieval was conducted after eight meetings. All of that data is recorded in a pre-prepared data table.

There are two instruments in this study: motivation test instruments totaling 15 points, and quality of life test instruments 26 question points. Before the instrument is used to obtain data, a test is first conducted. This test is intended to look at the validity of the instrument and the reliability of the instrument.

Researchers conduct pre-research observations in advance to determine the environment and condition of the subject to be studied, including to know the number of subjects to be studied. Researchers conducted motivational tests on all subjects that met the inclusion criteria in this study. After the test, the motivational results were obtained; researchers divided the subjects based on a predetermined range of motivation values (high and low). The researchers placed both high and low categories on both of each group in the experimental group and control group. In the experimental group (consisting of high and low motivation), researchers provided interventions in healthy lifestyle modules, while in the control group (consisting of high and low motivation) did not get interventions. Then, the results are entered into the data table to analyze the data further and prepare the research report.

Researchers used a data collection tool that is a healthy lifestyle module, motivation, and quality of life test questionnaire (WHOQOL-Breff). This WHOQOL-BREF instrument has been developed collaboratively in various parts of the world. The instrument consists of 26 question items where two questions about the quality of life in general and 24 other questions cover four domains. The four domains are:
a. Physical health, in item number 3, 4, 10, 15, 16, 17 and 18
b. Psychological in item number 5, 6, 7, 11, 19 and 26
c. Social relations in item number 20,21 , and 22
d. Environment in item number 8, 9, 12, 13, 14, 23, 24 and 25. 
This healthy lifestyle module instrument researchers designed themselves and modified researchers based on various sources (references) that researchers get. The scoring is 3 for good, 2 for medium, and 1 for bad, and a checklist $(\sqrt{ })$ in the column.

After the pretest data is obtained (the result of motivation and quality of life measurement), the next step is to determine the experimental and control groups. Furthermore, providing interventions is in the form of giving healthy lifestyle modules to the experimental group. Researchers conducted observations in both groups, and observations aimed to continuously monitor the subject's condition in general both in terms of adequacy of the number and general condition of the subject. After eight meetings after the subject underwent 4 dialysis cycles (1 month after the intervention), post-test data retrieval was conducted after eight meetings. All of that data is recorded in a pre-prepared data table.

The data obtained is analyzed using multiple linear regression analysis. Data analysis is done by looking at the number of checklist marks $(\sqrt{ })$ in each column. The number of checklists multiplied by the frequency in each column. The ratings are defined based on the gradation in which the value of score category multiplies the number of statement items in each section that is the determination of each category.

\section{RESULT}

The respondent consisted of 23 men $(71.9 \%)$ and nine women $(28.1 \%)$, and the majority was 50-55 years old as many as 17 people $(53.1 \%)$ while the lowest respondent age category 20 25 years as much as one person (3.1\%). In full, the respondent's age can be seen in Table 2 below:

\begin{tabular}{|c|c|c|}
\hline Age & $f$ & $\%$ \\
\hline $20-25$ & 1 & 3,1 \\
\hline $26-31$ & - & - \\
\hline $32-37$ & 3 & 9,4 \\
\hline $38-43$ & 8 & 25 \\
\hline $44-49$ & 3 & 9,4 \\
\hline $50-55$ & 17 & 53,1 \\
\hline Total & 32 & 100 \\
\hline
\end{tabular}

The healthy lifestyle module used in this study was designed in the form of a book. This research instrument contains several sections containing forms of healthy lifestyle arrangement. The instrument consists of (1) diet with a balanced menu; 2) drinking patterns; 3) regular and measurable exercise; 4) no smoking; 5) do not drink alcoholic beverages; 6) rest well; 7) get enough sleep; 8) stress control; 9) IDWG; 10) quality of life; 11) social relations; 12) leisure time; and 13) final evaluation.

Levene's test (homogeneity test) with F-test, meaning that if the variant is the same, then the t-test uses the equal output variances assumed, and if different variants use output, equal variances are not assumed. 
The study results consisted of descriptive statistics such as frequency, mean and standard deviations, assumptions test results, and hypotheses test results, which were then analyzed critically presented in a sequential or integrated manner. The explanation of the results section contains the results of data analysis. If the research is qualitative, the research findings can be conveyed in patterns, themes, tendencies, and motives that emerge from the data.

The above output shows an interaction between healthy lifestyle modules and motivation where the value $(\mathrm{F}=0.285 ; \mathrm{p}<0.05)$. This result is reinforced by the image below where it shows the existence of a pattern of line intersections. In the high-motivation group, the quality of life improved higher than in the low-motivation group.

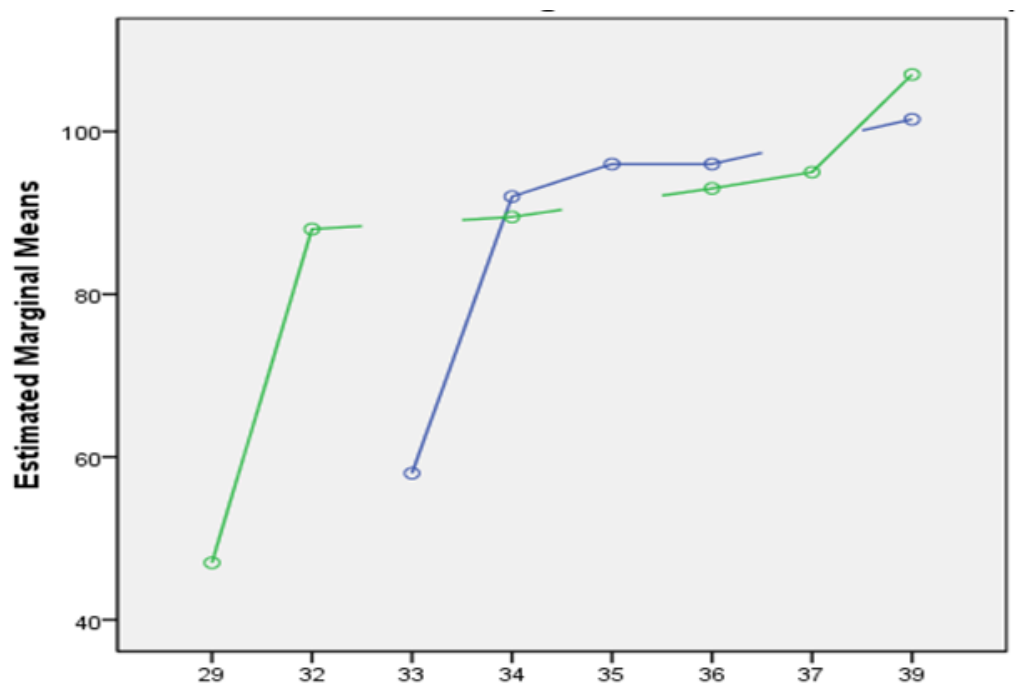

Figure 1 Improved quality of life-based on time and motivation level

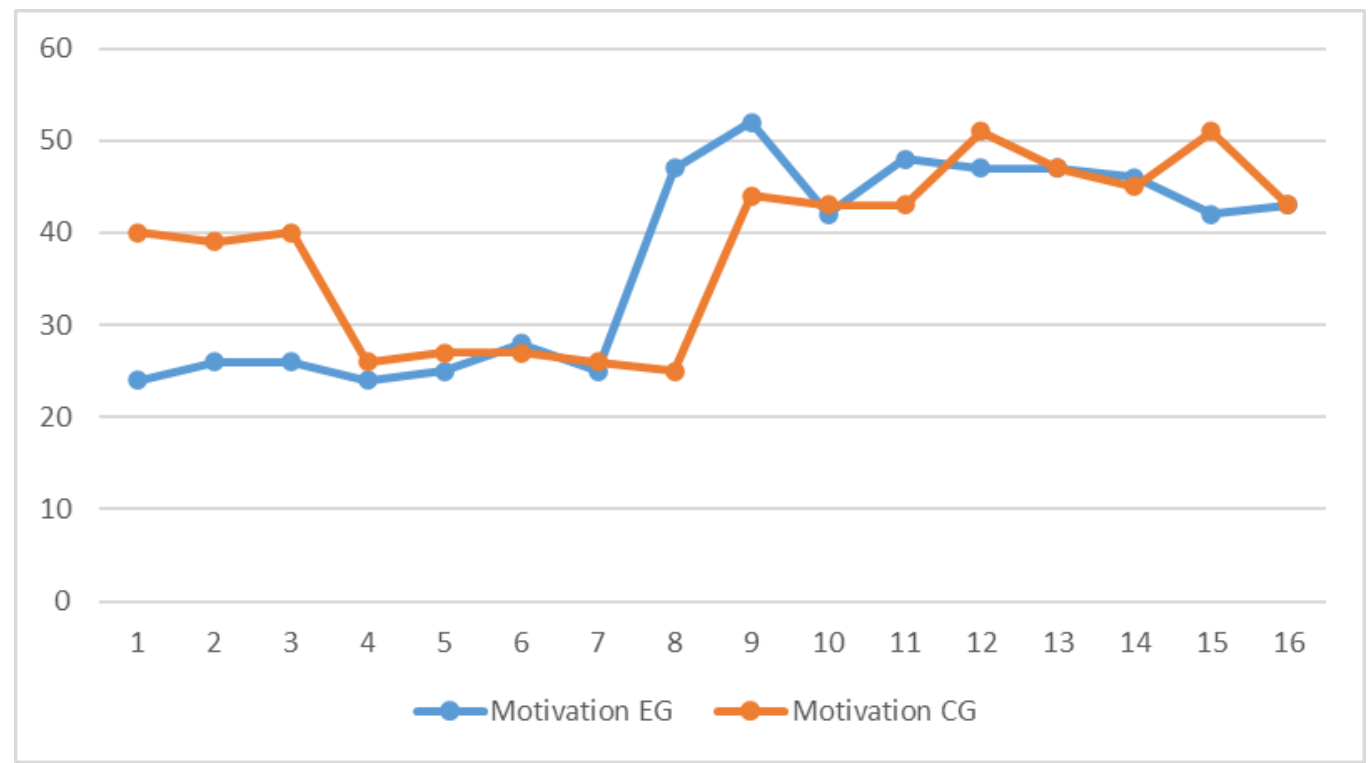

Figure 2 Comparison of results based on high and low motivation levels in the experimental group and control group on improving quality of life 


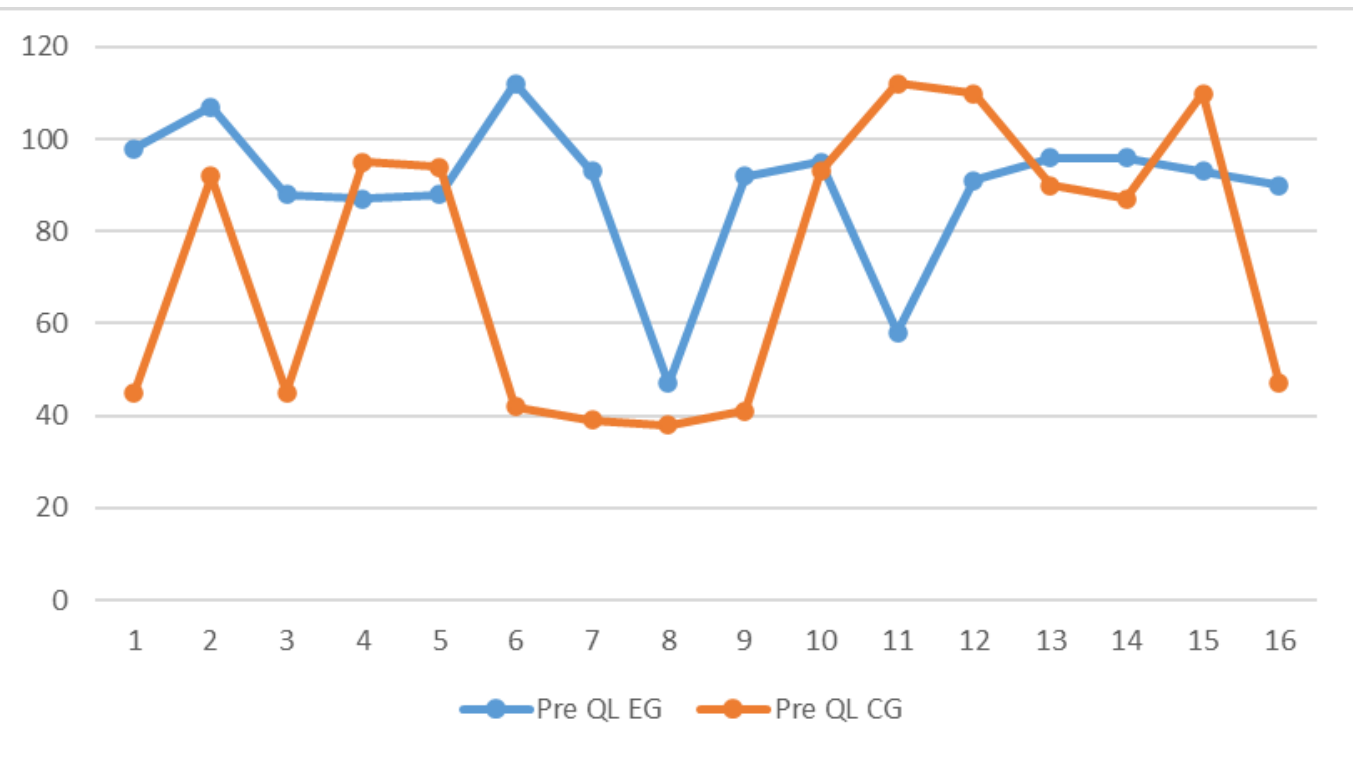

Figure 3 Comparison of results based on the quality of life pretest in the experimental and control group

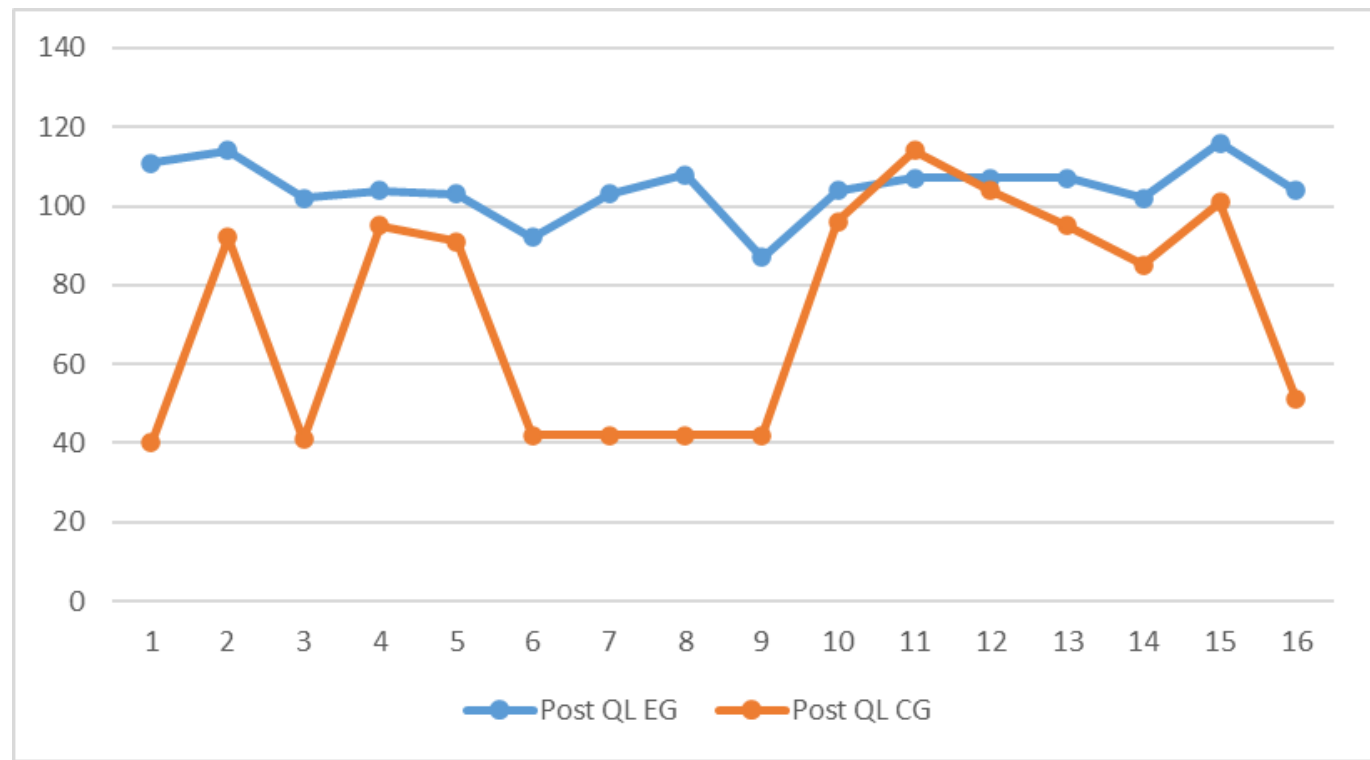

Figure 4 Comparison of results based on Post-test Quality of Life Improvement in Experiment group and Control Group

The image above shows that the experimental group has improved a healthy lifestyle outside the hemodialysis schedule from pretest to post-test, while the control group has a healthy lifestyle beyond a more hemodialysis schedule than the experimental group. The high-motivation experimental group improved quality of life better than the low-motivation group. 


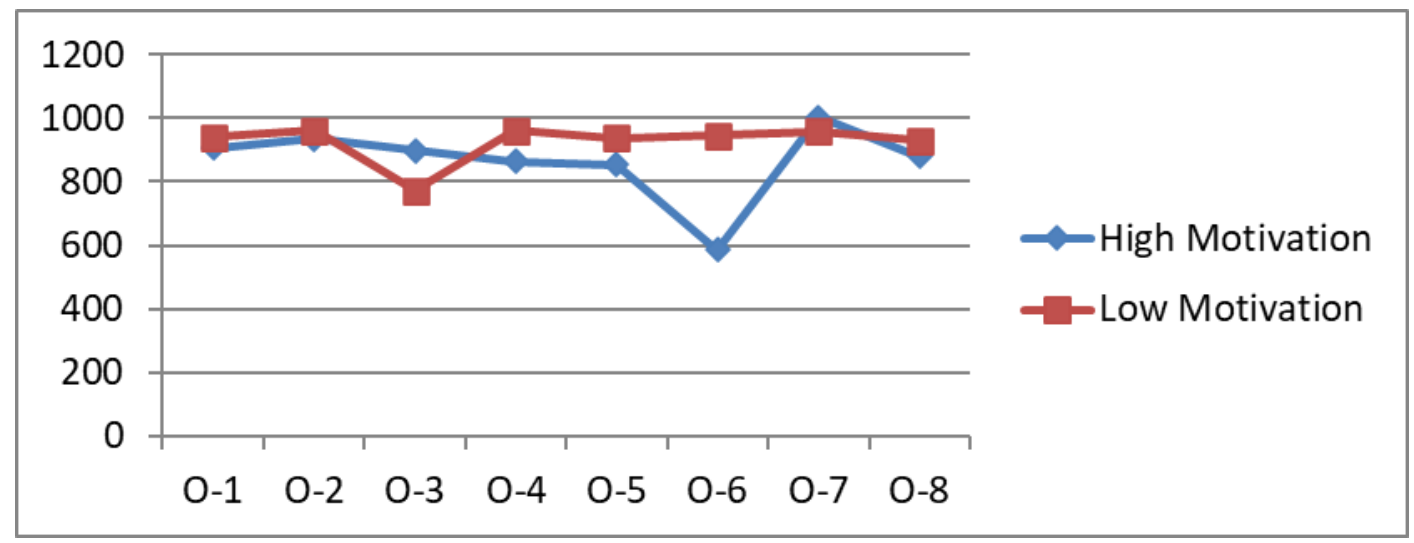

Figure 5 Observation of Healthy Lifestyle Module On Improving Quality of Life

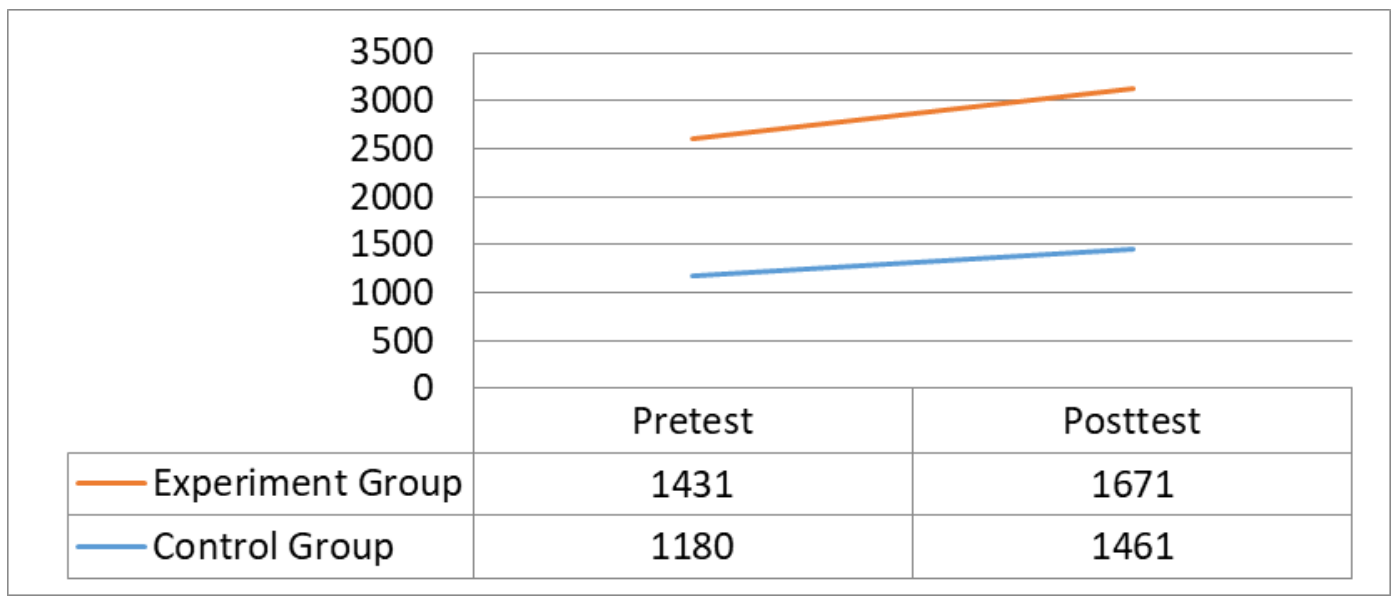

Figure 6 Quality of Life

From the output obtained, the significance value (Asym. Sig 2-tailed) is $<0,001$. Testing criteria, $\mathrm{H}_{0}$ is accepted if the $>0.05, \mathrm{H}_{0}$ is rejected if $<0.05$ then the significance value of 0.000 is less than $0.05 \mathrm{H}_{0}$ is rejected, so it is concluded because of the significance $(0.000<0.05)$ then $\mathrm{H}_{0}$ is rejected, meaning there is a difference between before and after being given a healthy lifestyle module towards improving quality of life.

\section{DISCUSSION}

The effect of the provision of healthy lifestyle modules on improving quality of life in chronic renal failure patients undergoing hemodialysis therapy is in line with research that has been conducted based on each domain of quality of life. Rahman, Rudiansyah, \& Triawanti (2013) stated that the quality of life of the respondent's physical health domain is in the moderate category $(47.8 \%)$ and low category $(43.2 \%)$ while the good category is only $(9.0 \%)$. Changes in physical health result in the limited activity of each chronic renal failure patient. The feeling of helplessness causes this limitation. These changes are also closely related to pain and anxiety, dependence on medical care, energy and fatigue, mobility, sleep and rest, daily life activities, and work capacity.

Zurmeli, Bayhakki, \& Utami (2015) stated that of the 54 respondents studied, 54\% of them had poor quality of life, including physical health, physiological state, level of independence, social relations (social support), personal beliefs, and socioeconomic status. Social relationships 
are reciprocal relationships between individuals, mutually influencing and based on awareness to help each other. Every individual must have a social relationship because a person was created as a social being that will not be separated from social interaction or social contact with individuals or groups. Healthy interpersonal relationships occur if the individuals involved feel close to each other while personal identity is retained. Poor social relationships will have implications for lifestyle forms that will ultimately impact the quality of life. The proper intervention of the social domain is better, especially in irreversible disease conditions should get very serious attention, and if this is not handled appropriately and quickly, then the implications are more and more. This finding is in line with the research conducted by Lestari \& Nurmala (2015) obtained that patients who have high motivation have a seven times chance to comply in undergoing hemodialysis compared to patients who have low motivation. Maslakha \&Santy (2014) explained that of the 59 respondents studied, (50.8\%) respondents in the category of non-compliance. Compliance in question is the patient's behavior in implementing the provisions made by health professionals in terms of treatment of hemodialysis therapy.

Comparing the research done with the results of this study, we can conclude that changes in lifestyle behavior can be controlled by forming a behavior arrangement and the provision of healthy lifestyle modules in this study. Significantly the results of behavioral changes were seen in the post-test results performed after the intervention was administered.

\section{CONCLUSION}

This study shows the interaction between healthy lifestyle modules and motivation in improving quality of life in chronic renal failure patients undergoing hemodialysis therapy in hemodialysis units. Recommendations of further research are by looking at the role of family support to the effectiveness of modules, motivation, culture, and customs to improve patients' quality of life.

\section{REFERENCES}

Aminah, S. (2012). Studi tingkat pengetabuan keluarga tentang perawatan lansia yang menderita gagal Ginjal kronik di Paviliun B2 Rumkital dr. Ramelan Surabaya. [Undergraduate thesis, Universitas Nahdhatul Ulama Surabaya]

Anees, M., Hameed, F., Mumtaz, A., Ibrahim, M., \& Saeed Khan, M. N. (2011). Dialysis-related factors affecting quality of life in patients on hemodialysis. Iranian journal of kidney diseases, 5(1), 9-14.

Brunner \& Suddarth. (2005). Keperawatan medical bedah. ed. 8 vol. 2. EGC.

Diyono, D., \& Indriati, R. (2017). Analisis gaya hidup (lifestyle) sebagai faktor resiko penyakit gagal ginjal kronis. KOS ALA: Jurnal Ilmu Kesehatan, 5(2), 147-151.

Fayers, P. M., \& Machin, D. (2013). Quality of life: The assessment, analysis and interpretation of patientreported outcomes. John Wiley \& Sons.

Hwang, J. C., Wang, C. T., \& Chien, C. C. (2007). Effect of climatic temperature on fluid gain in hemodialysis patients with different degrees of overhydration. Blood purification, 25(5-6), 473-479. 
Ipo, A., Aryani, T., \& Suri, M. (2018). Hubungan jenis kelamin dan frekuensi hemodialisa dengan kualitas hidup pasien gagal ginjal kronik yang menjalani hemodialisa di Rumah Sakit Umum Daerah Raden Mattaher Jambi. Jurnal Akademika Baiturrabim Jambi, 5(2), 46-55.

Kalantar-Zadeh, K., \& Aronoff, G. R. (2009). Hemoglobin variability in anemia of chronic kidney disease. Journal of the American Society of Nephrology, 20(3), 479-487.

Kimmel, P. L., Varela, M. P., Peterson, R. A., Weihs, K. L., Simmens, S. J., Alleyne, S., Amarashinge, A., Mishkin, G. J., Cruz, I., \& Veis, J. H. (2000). Interdialytic weight gain and survival in hemodialysis patients: effects of duration of ESRD and diabetes mellitus. Kidney International, 57(3), 1141-1151.

Kurniawati, A., \& Asikin, A. (2018). Gambaran tingkat pengetahuan penyakit ginjal dan terapi diet ginjal dan kualitas hidup pasien hemodialisis di Rumkital dr. Ramelan Surabaya. Amerta Nutrition, 2(2), 125-135.

Larasati, T. A. (2012). Kualitas hidup pasien diabetes melitus tipe 2 di RS Abdul Moeloek Propinsi Lampung. JUKE Unila, 2(1), 17-20.

Lestari, D. A. \& Nurmala, E. (2015). Hubungan motivasi pasien dengan kepatuban menjalani hemodialisa pada pasien gagal ginjal kronik di Rumah Sakit Umum Daerah Kraton Pekalongan. [Undergraduate thesis, Universitas Muhammadiyah Pekajangan Pekalongan]

Maslakha, L. \& Santy, W. H. (2015) Analisa pemahaman Discharge Planning dengan tingkat kepatuhan pasien gagal ginjal kronik (GGK) dalam menjalani Terapi Hemodialisis di Rumah Sakit Islam Jemursari Surabaya. Jurnal Ilmiah Kesehatan, 8(1), 49-57.

Maulida, A., Fadilah, A., \& Yulianto, M. (2019, August 27). Hubungan dukungan keluarga dengan kualitas hidup pasien hemodialisa di RSUD dr. Loekmono Hadi Kudus [Conference session]. Prosiding HEFA (Health Events for All): Pengembangan Penelitian dan Pengabdian Masyarakat Berbasis Luaran Kekayaan Intelektual, Kudus, Central Java, Indonesia. https://prosiding.stikescendekiautamakudus.ac.id/index.php/pros/article/view/35

Nurmanita, N., Rosita, A., \& Nurjayanti, D. (2020). Gambaran gaya hidup pasien gagal ginjal kronik di Ruang Hemodialisa RSUD dr. Harjono Ponorogo. WARTA BHAKTI HUS ADA MULIA: Jurnal Kesehatan, 7(1), 544-549.

Prakoso, F. A. (2011). Kajian riwayat gaya hidup pasien gagal ginjal kronik di Ruang Hemodialisa RSUD Kanjuruban Kepanjen Kabupaten Malang. Undergraduate thesis, Universitas Muhammadiyah Malang].

Ratnawati, R. (2014). Efektivitas Dialiser Proses Ulang (DPU) pada penderita gagal ginjal kronik (hemodialisa). Jurnal Ilmiah Widya, 1(1), 48-52.

Sari, T. N. I. (2018). Hubungan tingkat pengetabuan dengan gaya bidup pasien penyakit ginjal kronik di Ruang Hemodialisa RSUD dr. R. Koesma Tuban. [Undergraduate thesis, Poltekkes Kemenkes Surabaya).

Sulistyaningsih, D. R. (2021). Efektivitas Training Efikasi Diri pada pasien penyakit ginjal kronik dalam meningkatkan kepatuhan terhadap intake cairan. Majalah Ilmiah Sultan Agung, 50(128), 11-25.

Supriyadi, S., Wagiyo, W. \& Widowati, S. R. (2011). Tingkat kualitas hidup pasien gagal ginjal kronik terapi hemodialisis. KEMAS: Jurnal Kesehatan Masyarakat, 6(2), 107-112.

Wakhid, A., Wijayanti, E. L., \& Liyanovitasari, L. (2018). Hubungan efikasi Diri dengan kualitas hidup pasien gagal ginjal kronik yang menjalani hemodialisis. Journal of Holistic Nursing Science, 5(2), 56-63. 
Widayati, D., \& Lestari, N. (2017). Peningkatan kualitas hidup pada penderita gagal ginjal kronik yang menjalani terapi hemodialisa melalui psychological intervention di Unit Hemodialisa RSUD Gambiran Kediri. Jurnal Ilmu Kesehatan, 3(2), 6-11.

Widyastuti, R., Butar-Butar, W. R., \& Bebasari, E. (2014). Korelasi lama menjalani hemodialisis dengan indeks massa TUBUH pasien gagal ginjal kronik di RSUD Arifin Achmad Provinsi Riau pada Bulan Mei tahun 2014. Jurnal Online Mahasiswa Fakultas Kedokteran, 1(2), 1-12.

Zurmeli, Z., Bayhakki, B., \& Utami, G. T. (2015). Hubungan dukungan keluarga dengan kualitas hidup pasien gagal ginjal kronik yang menjalani terapi hemodialisis di RSUD Arifin Achmad Pekanbaru. Jurnal Online Mahasiswa Program Studi Ilmu Keperawatan Universitas Riau, 2(1), 670-681. 